\title{
Autopsy Cases in 2017- A Retrospective Study
}

\author{
Vijay Kumar AG, Kumar U*, Shivaramu MG and Vinay J \\ Department of Forensic Medicine \& Toxicology, India
}

Submission: May 11,2018; Published: May 16, 2018

*Corresponding author: Kumar U, Department of Forensic Medicine \& Toxicology, B G Nagara, Nagamangala Taluk, Mandya, Karnataka State, India, Tele: 9916735739; Email: vijay.fmt@rediffmail.com

\section{Abstract}

TAn autopsy (post-mortem examination, necropsy) is a specialized procedure that consists of examination of dead body to find out cause of death, manner of death, time since death and identification. It is conducted by forensic expert. In this retrospective study, all the cases autopsied during the period 1st January 2017 to 31st December 2017 were analyzed at the Department of Forensic Medicine \& Toxicology, Adichunchanagiri Institute of Medical Sciences, Mandya District, and Karnataka, India. During this study several epidemiological observations and their results have been considered. In the retrospective epidemiological study, totally 159 cases which are autopsied in 2017 at Department of Forensic Medicine \& Toxicology, Adichunchanagiri Institute of Medical Sciences is studied in detail. Road traffic accident cases constitute $47 \%$ of total cases since the medical college is next to national highway and national highway are the major source of road traffic accident in India. Poisoning cases constitutes $23 \%$ of total cases because the medical college located in rural area and due to severe drought from past 15 years, the farmers is forced commit to suicide because of lack of cultivation. Drowning constitutes $2.5 \%$ of total cases because medical college is surrounded by Kaveri and Hemavathi River. Snake bite constitutes 4.4\% of total cases because of deforestation which is rampaged in this area.

Keywords: Postmortem; Road Traffic Accident; Poisoning; Snake Bite; Drowning

\section{Introduction}

An autopsy (post-mortem examination, necropsy) is a specialized procedure that consists of examination of dead body to find out cause of death, manner of death, time since death and identification. It is conducted by forensic expert.

\section{Types}

a. Medico-Legal Autopsy is to find the cause and manner of death and to identify the deceased. They are performed in all suspicious case of death by forensic expert after receiving inquest report from law agency [1].

b. Clinical or Pathological autopsies are performed by pathologist to determine, clarify, or confirm medical disease that remained unknown or unclear prior to the patient's death.

c. Anatomical or academic autopsies are performed by medical students to study anatomy. d. Virtual or medical imaging autopsies are performed utilizing imaging technology only, primarily magnetic resonance imaging (MRI) and computed tomography (CT) [2]. Forensic medicine is the branch of medicine, which deals with the application of medical knowledge in the administration of justice. Toxicology tests will be done in forensic science laboratory to reveal the presence of one or more chemical "poisons"

\section{Materials and Methodology}

This is a retrospective study, in which all the cases which are autopsied during the period 1st January 2017 to 31st December 2017 were studied and anlyzed at the Department of Forensic Medicine \& Toxicology, Adichunchanagiri Institute of Medical Sciences, Mandya District, Karnataka, India. During this study several epidemiological observations and their results have been considered.

Table 1

\begin{tabular}{|c|c|c|c|}
\hline Si. no & Manner of death & Number of cases & \% \\
\hline 1 & Rta & 74 & 47 \\
\hline 2 & Poisoning & 37 & 23 \\
\hline 3 & Hanging & 10 & 6 \\
\hline 4 & Assault & 04 & 2.5 \\
\hline 5 & Lightning & 04 & 2.5 \\
\hline
\end{tabular}


Journal of Forensic Sciences \& Criminal Investigation

\begin{tabular}{|c|c|c|c|}
\hline 6 & Drowning & 04 & 2.5 \\
\hline 7 & Natural death & 14 & 8.8 \\
\hline 8 & Snake bite & 07 & 4.4 \\
\hline 9 & Burns & 02 & 1.2 \\
\hline 10 & Fall from height & 01 & 0.6 \\
\hline 11 & Complications of surgery & 02 & 1.2 \\
\hline Total & 159 & 100 & \\
\hline
\end{tabular}

Inclusion criteria: all the cases which are autopsied in 2017 at Department of Forensic Medicine \& Toxicology, Adichunchanagiri Institute of Medical Sciences Table 1.

\section{Results}

\section{Discussion}

In the retrospective epidemiological study, totally 159 cases which are autopsied in 2017 at Department of Forensic Medicine \& Toxicology, Adichunchanagiri Institute of Medical Sciences is studied in detail. Road traffic accident cases constitute $47 \%$ of total cases since the medical college is next to national highway and national highway are the major source of road traffic accident in India. Poisoning cases constitutes $23 \%$ of total cases because the medical colleges located in rural area and due to severe drought from past 15 years, the farmers are forced commit to suicide because of lack of cultivation. Drowning constitutes $2.5 \%$ of total cases because medical college is surrounded by kaveri and hemavathi river. Snake bite constitutes $4.4 \%$ of total cases because of deforestation which is rampaged in this area. According to a study by Pathak et al. totally 182 cases of road traffic accident has occurred in and around the tertiary care hospital. All the information was collected through questionnaire, hospital records and on-site visit [3].

In a study conducted by Nilambar Jha et al. totally 726 road traffic accidents were recorded, There were $83 \%$ male and $17 \%$ female accident victims. Laborers were the highest (29.9\%) among the victims. The highest number of accidents took place in the month of January (12.9\%) and on Sundays (17.1\%). The occupants of the various vehicles constituted the large (45\%) group of the victims. Among the motorized vehicles, two wheeler drivers were more $(31.1 \%)$ involved in accidents. Out of 254 drivers $14.9 \%$ were found to have consumed alcohol [4]. A case study done in Hyderabad shows increase in the vehicles since last 10 years has put lot of pressure on the existing roads and ultimately resulting in road accidents. It is estimated that since 2001 there is an increase of 202 percent of two wheeler and 286 percent of four wheeler vehicles with no road expansion. A study done by Subash Vijay Kumar et al. [5] 2,226 patients were admitted to the hospital with different poisonings.

The overall case fatality rate was $8.3 \%(\mathrm{n}=186)$. More detailed data from 2007 reveals that two-third of the patients were $21-30$ years old, $5.12 \%(n=114)$ were male and $3.23 \%$ (n $=72$ ) were female, who had intentionally poisoned themselves
[6]. In another retrospective study of two years from 2010 to 2011 done in the mortuary of Rangaraya Medical College, Kakinada, Andhra Pradesh. We studied total 1315 cases in two years. Out of this 90 cases were drowning. It occupies $5^{\text {th }}$ place in the cause of death. Out of 90 cases the total number of known cases were $73(81.11 \%)$ and unknown cases were $17(18.88 \%)$, 57 were males (63.33\%) and 33 were females (36.67\%). 41 cases were married, in which 23 males (47.32\%) and 18 females $(42.55 \%)$ and 32 cases are unmarried out of which 21 are males (50.31\%) and 11 females (22.09\%) [7]. Hayat AS has conducted a descriptive study at 4 medical wards of Loquat University Hospital Hyderabad/Jamshoro, Sindh from 1st January 2006 to December 2006. One hundred cases with history of snakebite were analyzed. Both genders were included in study. Patients with history of trauma, insect bite or thorn prick were excluded from the study. Clotting time (CT) was the main bedside procedure, to assess the degree of envenomation [8].

\section{Conclusion}

From this study we proved that maximum casualties are occurring in the above said area are due to road traffic accident. National highway authority of India should implement a strict traffic rules and highway should be properly maintained to reduce the accidental deaths. By joining the rivers adequate amount of water should be provided to the farmers that directly affects their income and automatically reduces the suicidal attempts. Safety barricade should be installed in all the water channels and water dams that reduce the accidental drowning. Deforestation should be avoided, that reduces the chances of snake contacts with human.

\section{References}

1. Strasser, Russell S (2008) Autopsies In Ayn Embar-seddon, Allan D Pass (eds.). Forensic Science. Salem Press. P95-96.

2. Roberts IS, Benamore RE, Benbow EW, Lee SH, Harris JN, et al. (2012) Post-mortem imaging as an alternative to autopsy in the diagnosis of adult deaths: A validation study. The Lancet 379(9811): 136-142.

3. Pathak SM, Jindal AK, Verma AK, Mahen A (2014) an epidemiological study of road traffic accident cases admitted in a tertiary care hospital. Med J Armed Forces India 70(1): 32-35.

4. Nilambar J, Srinivasa DK, Gautam R, Jagdish S (2004) Epidemiological study of road traffic accident cases: a study from south india. Indian Journal of Community Medicine 29(1): 20-24.

5. Bhagyaiah, Shrinagesh B (2014) Traffic Analysis and Road Accidents: A Case Study of Hyderabad using GIS. IOP Conf Series Earth and Environmental Science 20: 012026. 
6. Subash VK, Venkateswarlu B, Sasikala M, Vijay KG (2010) A study on poisoning cases in a tertiary care hospital. J Nat Sci Biol Med 1(1): 35 39.

7. Ranga R, Jakkam S, Prasad (2014) A Comprehensive Study of Drowning in and Around Kakinada, Two Years Retrospective Study Sch. J App Med Sci 2(4D): 1397-1401.

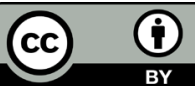

This work is licensed under Creative Commons Attribution 4.0 License

DOI: $10.19080 /$ JFSCI.2018.09.555751
8. Hayat AS, Khan AH, Shaikh TZ, Ghouri RA, Shaikh N (2008) Study of snake bite cases at Liaquat University Hospital Hyderabad/Jamshoro. J Ayub Med Coll Abbottabad 20(3):125-127.

Your next submission with Juniper Publishers will reach you the below assets

- Quality Editorial service

- Swift Peer Review

- Reprints availability

- E-prints Service

- Manuscript Podcast for convenient understanding

- Global attainment for your research

- Manuscript accessibility in different formats (Pdf, E-pub, Full Text, Audio)

- Unceasing customer service

Track the below URL for one-step submission https://juniperpublishers.com/online-submission.php 